\title{
Pemodelan Penurunan Pondasi Struktur Bangunan di Tanah Lunak Kota Banjarmasin Menggunakan ANSYS
}

\author{
Darmansyah Tjitradi*1, Eliatun², Oktafianus Steven Tjitradi ${ }^{3}$ \\ ${ }^{1}$ Program Studi Pendidikan Profesi Insinyur Universitas Lambung Mangkurat \\ ${ }^{2}$ Program Studi S1 Teknik Sipil Universitas Lambung Mangkurat \\ ${ }^{3}$ Mahasiswa Program Studi S1 Teknik Sipil Universitas Lambung Mangkurat \\ Email:*tjitradi_syah@ulm.ac.id
}

Received 06 June 2021; Reviewed 29 July 2021; Accepted 17 August 2021

Journal Homepage: http://jurnal.borneo.ac.id/index.php/borneoengineering

\begin{abstract}
Soil in Banjarmasin City is of soft clay type had a very low bearing capacity. Hence, it is normal for buildings in this area to have gelam wooden (Melaleuca sp) piles as part of the foundation. Foundations based on gelam wooden piles rely on friction which results in the building to experience differential settlement, tilt, and cracks on the structural elements. The modelling aims at understanding the effects of using tie beams on the pattern of structural damage in buildings that experience differential settlement on soft soil. The settlement of this foundation is analyzed using a FEM model using ANSYS Ed. software by taking fifteen building structural models with brick walls that will be idealized using solid elements. The frame structure is loaded according to SNI 1727:2013 and due to settlement at the support until it collapses. The result suggests that the use of tie beams in foundations on soft soil does affect the damage pattern. On hard soil, it does not bring such effects but instead, it increased the degree of static indeterminacy of the structure. In the case of single-span frame, the crack pattern resembles an inverted "V" if the settlement takes place at the side supports. In double-span portals, on the other hand, the crack pattern of brick walls resembles a letter " $V$ " if the settlement takes place at the side supports, and an inverted " $V$ " if it happens between supports.
\end{abstract}

Keywords: crack, brick wall, foundation settlement, ANSYS

\begin{abstract}
Abstrak
Tanah di kota Banjarmasin termasuk jenis tanah lempung lunak yang memiliki daya dukung sangat rendah, sehingga umumnya bangunan di daerah ini mengunakan pondasi kayu tiang gelam (Melaleuca sp). Penggunaan pondasi kayu tiang gelam hanya mengandalkan lekatan (friction), sehingga mengakibatkan bangunan mengalami penurunan pondasi yang tidak seragam (differential settlement), kemiringan, dan keretakan pada elemen struktur. Pemodelan ini bertujuan untuk mengetahui pengaruh penggunaan balok sloof terhadap pola kerusakan struktur bangunan yang mengalami penurunan pondasi yang tidak seragam di tanah lunak. Penurunan pondasi ini di analisis dengan model FEM yang menggunakan software ANSYS Ed. dengan mengambil lima belas model struktur bangunan dengan dinding batu bata yang akan diidealisasi dengan menggunakan elemen solid. Struktur portal dibebani dengan beban standar bangunan menurut SNI 1727:2013, dan beban akibat penurunan tumpuan sampai mengalami keruntuhan. Hasil penelitian ini adalah penggunaan balok sloof pada pondasi di tanah lunak akan mempengaruhi pola kerusakan elemen struktur, dan pada tanah keras tidak mempengaruhi pola kerusakan elemen struktur tetapi akan meningkatkan derajat ketidaktentuan statis struktur. Pada portal satu bentang pola retak dinding bata membentuk huruf $V$ terbalik jika terjadi penurunan di tumpuan tepi, sedangkan pada portal dua bentang pola retak dinding bata membentuk huruf $V$ jika terjadi penurunan di tumpuan tepi, dan membentuk huruf $V$ terbalik jika terjadi penurunan di tumpuan tengah.
\end{abstract}

Kata kunci: retak, dinding bata, penurunan pondasi, ANSYS 


\section{Pendahuluan}

Kota Banjarmasin merupakan daerah yang mayoritas lahannya adalah lahan rawa dan sebagian terdiri dari tanah gambut yang mempunyai daya dukung tanah yang sangat lunak sekali. Daya dukung tanah kerasnya terletak sangat jauh sekali yaitu berkisar antara $25 \mathrm{~m}$ sampai dengan $50 \mathrm{~m}$, sehingga pondasi yang biasa digunakan termasuk kategori pondasi dalam. Masyarakat lokal daerah ini dalam membangun suatu bangunan biasa menggunakan pondasi dalam berupa pondasi tiang kayu gelam yang hanya mengandalkan lekatan (friction). Pondasi kayu gelam (Melaleuca $s p$ ) ini berasal dari pohon gelam yang tumbuh di daerah rawa dengan diameter berkisar antara 8 sampai dengan $15 \mathrm{~cm}$, pondasi tersebut kemudian dihubungkan dengan balok sloof agar apabila terjadi penurunan pondasi diharapkan terjadi penurunan pondasi yang seragam. Penggunaan pondasi tiang yang hanya mengandalkan lekatan dan balok sloof yang terbuat dari beton telah menyebabkan banyak sekali terdapat bangunan miring di kota Banjarmasin serta elemen-elemen struktur seperti balok, kolom, pondasi dan dinding bata banyak yang mengalami keretakan.

Kestabilan struktur bergantung pada sifat geoteknik pondasi seperti kekuatan geser, permeabilitas, dan kompresibilitas tanah. Kekuatan rendah dari tanah yang sangat organik (hasil dari penumpukan sampah-sampah organik dari tumbuhan yang telah mengalami pembusukan) seperti tanah gambut dapat menyebabkan penurunan yang berlebihan dan kegagalan struktur atas, misalnya terjadi keretakan pada struktur atas atau perkerasan jalan utama (D. C. Wijeyesekera, dkk., 2016). Selain itu tanah gambut yang lunak sangat rentan terhadap gerakan tanah yang disebabkan oleh kelembaban, dan tidak mampu menahan beban yang diberikan oleh suatu struktur karena kadar air lapangannya yang luar biasa tinggi yang kadang-kadang bisa mencapai 800\% (Huat, dkk. 2013).

Tanah lunak biasanya mempunyai ciri sebagai tanah dengan kekuatan geser rendah, sangat mudah dimampatkan dan permeabilitas rendah (Huat, dkk. 1995), (Huat,dkk., 2005). Secara umum, kendala konstruksi pada lapisan lunak ini adalah daya dukung yang tidak mencukupi, penurunan pasca konstruksi yang berlebihan dan ketidakstabilan pada penggalian. Secara teoritis, masalah penurunan dapat diartikan sebagai deformasi pada tanah akibat tegangan yang diberikan (N. O. Mohamad, dkk., 2016). Skempton dan MacDonal (1955) menyarankan batas-batas penurunan maksimum seperti pada Tabel 1. Dengan menggunakan nilai batas penurunan maksimum ini maka dapat menjadi dasar dalam pemodelan penurunan pondasi pada tanah lempung yang berkisar antara 65 sampai dengan $100 \mathrm{~mm}$ (Rufaizal C. M., dkk., 2019), (Hardiyatmo, H. C, 2002).

Tabel 1 Batas Penurunan Maksimum

\begin{tabular}{lc}
\hline \multicolumn{1}{c}{ Jenis Pondasi } & Batas Penurunan Maksimum (mm) \\
\hline Pondasi terpisah pada tanah lempung & 65 \\
Pondasi terpisah pada tanah pasir & 40 \\
Pondasi rakit pada tanah lempung & $65-100$ \\
Pondasi rakit pada tanah pasir & $40-65$ \\
\hline
\end{tabular}

Penurunan izin dari suatu bangunan, bergantung kepada beberapa faktor yang meliputi jenis, tinggi, kekakuan, fungsi bangunan, serta besar dan kecepatan penurunan.

Jika penurunan berjalan lambat, semakin besar kemungkinan struktur untuk menyesuaikan diri terhadap penurunan yang terjadi tanpa adanya kerusakan struktur oleh pengaruh rangkak atau (creep). Oleh karena itu dengan alasan tersebut kriteria penurunan pondasi pada tanah pasir dan pada tanah lempung berbeda (Komarudin, 2017). Selain itu berdasarkan hasil penelitian Reza J.C., dkk. (2010) dikatakan bahwa perbedaan penurunan antara pondasi yang ada yang disebabkan oleh peningkatan tegangan dari konstruksi baru. Struktur baru sering kali dibangun di satu sisi struktur lama yang menimbulkan peningkatan tegangan di sisi yang berdekatan, sehingga pondasi atau bagian 
pondasi yang lebih dekat dengan struktur baru lebih banyak mengalami penurunan dibandingkan dengan struktur yang lebih jauh.

Penelitian ini menggunakan model kurva tegangan-regangan beton yang tidak terkekang menurut Kent-Park (1971) (Darmansyah T, 2006) untuk mewakili material beton mutu normal, yaitu:

a) Daerah $\mathrm{AB}: \varepsilon_{c} \leq 0.002$

$$
\mathrm{f}_{\mathrm{c}}=\mathrm{f}_{\mathrm{c}}^{\prime} \cdot\left[\frac{2 \cdot \varepsilon_{\mathrm{c}}}{0.002}-\left(\frac{\varepsilon_{\mathrm{c}}}{0.002}\right)^{2}\right]
$$

b) Daerah BC: $0.002 \leq \varepsilon_{\mathrm{c}} \leq \varepsilon_{50 \mathrm{u}}$

$$
\mathrm{f}_{\mathrm{c}}=\mathrm{f}_{\mathrm{c}}^{\prime} \cdot\left[1-\mathrm{z} \cdot\left(\varepsilon_{\mathrm{c}}-0.002\right)\right]
$$

Dimana:

$$
\begin{aligned}
& z=\frac{0.50}{\frac{3+0.002 \cdot f_{c}^{\prime}}{f_{c}^{\prime}-1000}-0.002} \\
& \varepsilon_{50 u}=\frac{3+0.002 \cdot f_{c}^{\prime}}{f_{c}^{\prime}-1,000}
\end{aligned}
$$

Tujuan dari penelitian ini adalah untuk mengetahui pengaruh penggunaan balok sloof dan tanpa sloof terhadap pola kerusakan struktur bangunan satu bentang dan dua bentang yang mengalami penurunan pondasi yang tidak seragam di tanah lunak kota Banjarmasin. Pemodelan kerusakan bangunan dilakukan dengan menggunakan software ANSYS Ed. yang berlisensi terhadap portal struktur beton dengan dinding pasangan batu bata.

\section{Pemodelan Struktur}

Penurunan pondasi pada struktur beton ini akan dimodelkan dengan software ANSYS yang akan dibebani dengan beban standar bangunan menurut SNI 1727:2013, dan beban akibat penurunan tumpuan. Konfigurasi model struktur beton dengan variasi penurunan tumpuan ditunjukkan pada Gambar 1 dan Tabel 2.

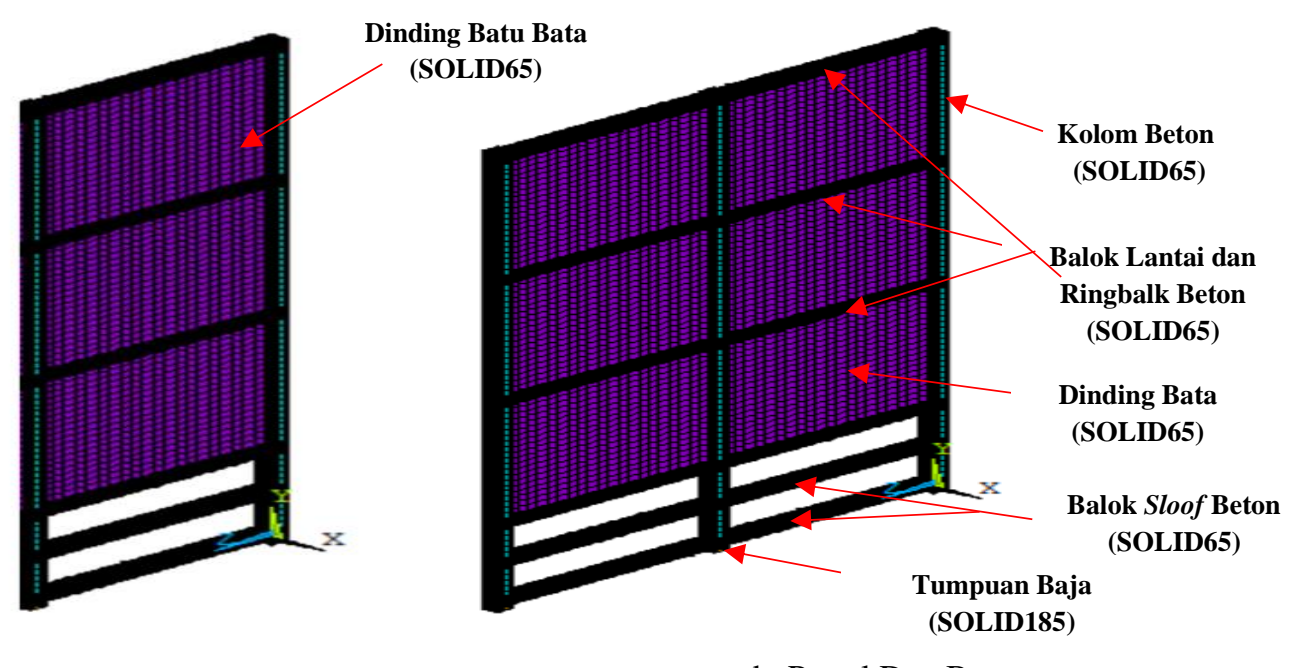

a. Portal Satu Bentang

b. Portal Dua Bentang

Gambar 1. Pemodelan Struktur Beton dengan balok sloof, dan dinding bata menggunakan Software ANSYS 
Model bangunan PB1-S2-0, PB1-S1-0, PB1-TS-0, PB2-S2-0, PB2-S1-0, dan PB2-TS-0 merupakan perwakilan kondisi bangunan yang berada di tanah keras atau memiliki daya dukung tanah yang sangat besar, sehingga diasumsikan tidak terjadi penurunan pondasi (dimodelkan jenis tumpuan jepit). Sedangkan model bangunan yang lainnya merupakan perwakilan dari struktur bangunan yang mengalami penurunan yang tidak seragam (dimodelkan jenis tumpuan dengan kondisi batas $\mathrm{U}_{\mathrm{y}}$ tidak sama dengan nol). Pengaruh interaksi tanah dan struktur serta pengaruh tulangan lentur dan geser tidak diperhitungkan dalam pemodelan ini.

Tabel 2 Konfigurasi Model Struktur Beton

\begin{tabular}{|c|c|c|c|c|}
\hline \multirow[b]{2}{*}{ No } & \multirow{2}{*}{$\begin{array}{c}\text { Kode } \\
\text { Benda Uji }\end{array}$} & \multicolumn{3}{|c|}{ Beban Akibat Penurunan Tumpuan (mm) } \\
\hline & & $\begin{array}{c}\text { Tumpuan Kiri } \\
\text { (P) }\end{array}$ & $\begin{array}{c}\text { Tumpuan Tengah } \\
\text { (T) }\end{array}$ & $\begin{array}{c}\text { Tumpuan Kanan } \\
\text { (P) }\end{array}$ \\
\hline 1 & PB1-S2-0 & 0 & - & 0 \\
\hline 2 & PB1-S2-P & 0 & - & 100 \\
\hline 3 & PB1-S1-0 & 0 & - & 0 \\
\hline 4 & PB1-S1-P & 0 & - & 100 \\
\hline 5 & PB1-TS-0 & 0 & - & 0 \\
\hline 6 & PB1-TS-P & 0 & - & 100 \\
\hline 7 & PB2-S2-0 & 0 & 0 & 0 \\
\hline 8 & PB2-S2-T & 0 & 100 & 0 \\
\hline 9 & PB2-S2-P & 0 & 0 & 100 \\
\hline 10 & PB2-S1-0 & 0 & 0 & 0 \\
\hline 11 & PB2-S1-T & 0 & 100 & 0 \\
\hline 12 & PB2-S1-P & 0 & 0 & 100 \\
\hline 13 & PB2-TS-0 & 0 & 0 & 0 \\
\hline 14 & PB2-TS.T & 0 & 100 & 0 \\
\hline 15 & PB2-TS-P & 0 & 0 & 100 \\
\hline
\end{tabular}

Keterangan kode benda uji:

PB1 = Portal Satu Bentang, dan PB2 = Portal Dua Bentang, S1 = Balok Sloof 1, S2 = Balok Sloof 2, dan TS $=$ Tanpa Sloof, $O=$ tanpa penurunan tumpuan, $T=$ penurunan tumpuan tengah, $P=$ penurunan tumpuan pinggir/ tepi (kiri/kanan)

\section{Pemodelan Numerik}

\subsection{Elemen Beton}

Elemen beton dimodelkan dengan menggunakan model 8 (nodal) elemen solid (SOLID65) dengan tiga derajat kebebasan pada setiap titiknya dan terjadi translasi pada arah x, y, and z (Gambar 2). Elemen ini juga mempunyai kemampuan untuk berdeformasi plastis, retak dalam arah $\mathrm{x}, \mathrm{y}$, dan $\mathrm{z}$. (L. Dahmani, et.al, 2010).

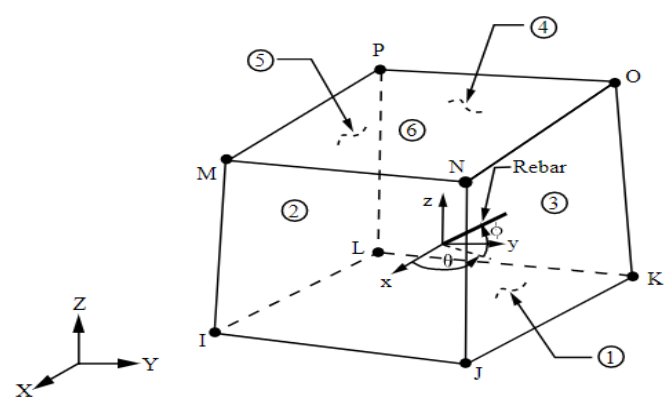

Gambar 2. Model 3D Elemen Beton SOLID 65 
Model tegangan-regangan beton yang tidak terkekang menurut Kent-Park (1971) ditentukan berdasarkan persamaan 1 s.d. 4 dengan hasil pada Tabel 3 .

Tabel 3 Model tegangan-regangan beton yang tidak terkekang menurut Kent-Park (1971)

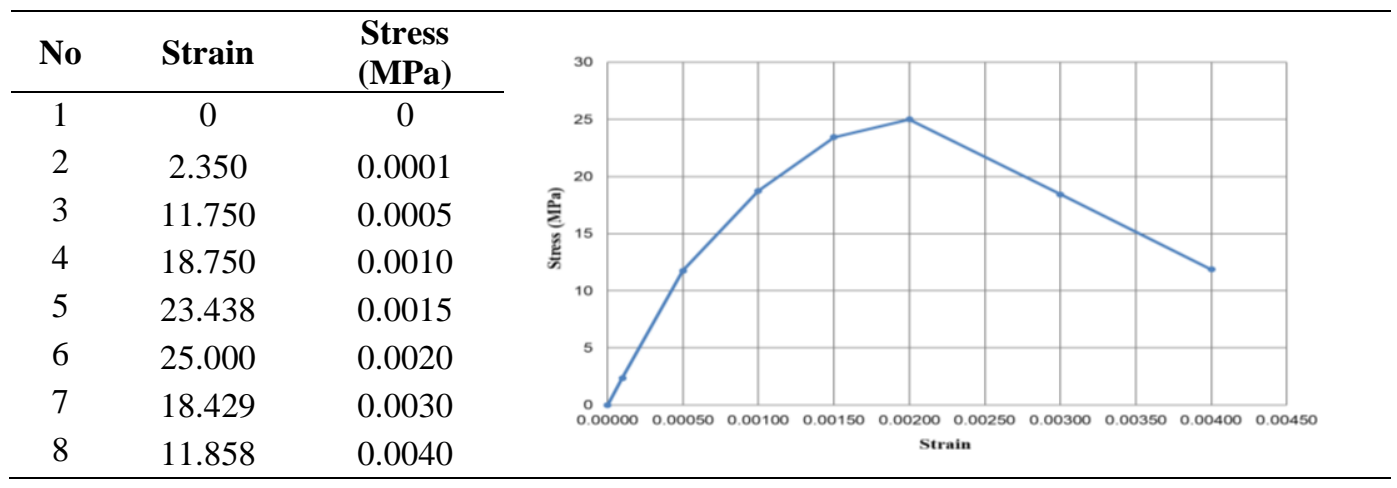

Data parameter beton dan sifat material beton yang digunakan dalam pemodelan ANSYS ditunjukkan pada Tabel 4 dan Tabel 5.

Tabel 4 Data Parameter Beton SOLID 65 (Nonlinear - Inelastic - Non-metal plasticity Concrete65)

\begin{tabular}{lcc}
\hline \multicolumn{1}{c}{ Parameter } & Nilai & Keterangan \\
\hline Open shear transfer coefficient & 0.20 & \\
Closed shear transfer coefficient & 0.60 & \\
Uniaxial cracking stress & $3.50 \mathrm{MPa}$ & $\left(\mathrm{f}_{\mathrm{r}}=0,70 \cdot \sqrt{ } \mathrm{f}_{\mathrm{c}}{ }^{\prime}\right)$ \\
Uniaxial crushing stress & $25 \mathrm{MPa}$ & $\left(\mathrm{f}_{\mathrm{c}}{ }^{\prime}\right)$ \\
Tensile crack factor & 0.60 & \\
\hline
\end{tabular}

Tabel 5 Data Sifat Material Beton SOLID 65 (Linear Isotropic)

\begin{tabular}{lc}
\hline \multicolumn{1}{c}{ Sifat Material } & Nilai \\
\hline Modulus Elastisitas Beton, $\mathrm{E}_{\mathrm{c}}$ & $2.35 \times 10^{4} \mathrm{MPa}$ \\
Poisson Rasio, $v$ & 0,20 \\
\hline
\end{tabular}

Catatan: berat sendiri beton dimasukan dalam pembebanan

Pola retak beton berdasarkan hasil dari software ANSYS Ed. ditunjukkan dengan simbol seperti pada Gambar 3. Beton yang mengalami crushing ditunjukkan dengan simbol tetrahedron merah, retak pertama (first crack) dengan lingkaran merah, retak kedua (second crack) dengan lingkaran hijau dan retak ketiga (third crack) dengan lingkaran biru. Retak dapat terjadi pada tiga bidang yang berbeda, setelah itu beton kehilangan kekakuan, tetapi masih dapat memikul sedikit tegangan geser. Retak juga dapat menutup (closed crack), tetapi hanya sebagian dari tahanan gesernya yang pulih (German Diaz. 2010).

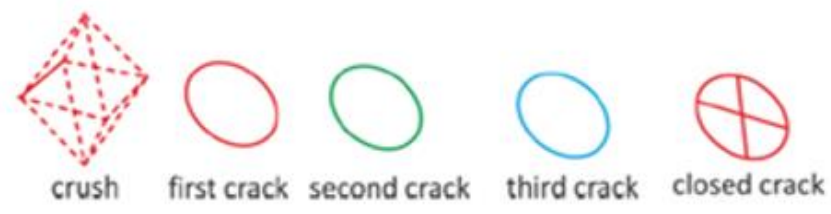

Gambar 3. Simbol retak yang akan ditunjukan oleh elemen SOLID 65 


\subsection{Material Tumpuan Baja (Support)}

Tumpuan baja dimodelkan dengan menggunakan model 8 elemen Solid (SOLID185) dengan tiga derajat kebebasan pada setiap titiknya dan terjadi translasi pada arah $\mathrm{x}, \mathrm{y}$, and z (Gambar 4). Data sifat material tumpuan baja yang digunakan dalam pemodelan ditunjukkan pada Tabel 6 .

Tabel 6. Data Sifat Material Tumpuan Baja SOLID 185 (Linear Isotropic)

\begin{tabular}{lc}
\hline \multicolumn{1}{c}{ Sifat Material } & Nilai \\
\hline Modulus Elastisitas Baja, $\mathrm{E}_{\mathrm{s}}$ & $2 \times 10^{5} \mathrm{MPa}$ \\
Poisson Rasio, $v_{\mathrm{s}}$ & 0.30 \\
\hline
\end{tabular}

Catatan: berat sendiri tumpuan baja dimasukan dalam pembebanan

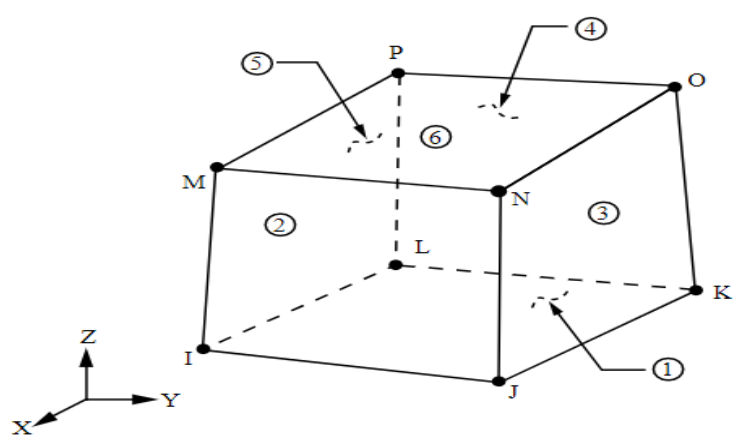

Gambar 4. Model 3D Elemen Baja SOLID185

\subsection{Elemen Batu Bata (Brick)}

Elemen batu bata dimodelkan dengan menggunakan model 8 elemen solid (SOLID65) (Gambar 2). Data parameter batu bata dan sifat material batu bata yang akan digunakan dalam pemodelan ANSYS mengunakan hasil penelitian Ch. V. Uday Vyas, dkk., 2010 ditunjukkan pada Tabel 7 s.d. 9.

Tabel 7 Data Sifat Material Batu Bata SOLID 65 (Linear Isotropic)

\begin{tabular}{lc}
\hline \multicolumn{1}{c}{ Sifat Material } & Nilai \\
\hline Modulus Elastisitas Beton, $\mathrm{E}_{\mathrm{c}}$ & $1.45 \times 10^{4} \mathrm{MPa}$ \\
Poisson Rasio, $v$ & 0.18 \\
\hline
\end{tabular}

Tabel 8 Data Parameter Elemen Batu Bata SOLID 65 (Nonlinear - Inelastic - Non-metal plasticity - Concrete 65)

\begin{tabular}{lc}
\hline \multicolumn{1}{c}{ Parameter } & Nilai \\
\hline Open shear transfer coefficient & 0.2 \\
Closed shear transfer coefficient & 0.5 \\
Uniaxial cracking stress & $0.71 \mathrm{MPa}$ \\
Uniaxial crushing stress & $5 \mathrm{MPa}$ \\
\hline
\end{tabular}


Tabel 9 Model Tegangan-Regangan Batu Bata (Nonlinear-Elastic-Multilinear Elastic)

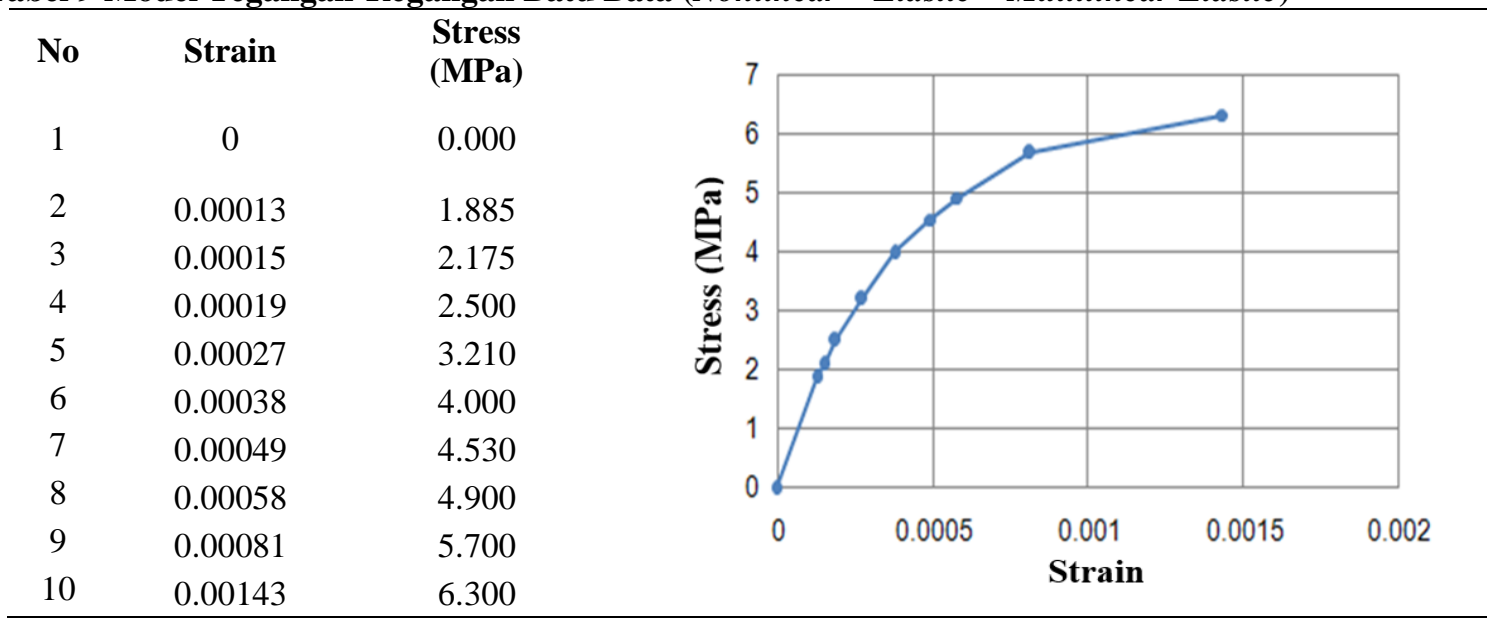

Secara keseluruhan data pemodelan numerik struktur beton dan dinding pasangan batu bata dengan software ANSYS Ed. ditunjukkan pada Tabel 10.

Tabel 10 Data Pemodelan Struktur Beton dengan ANSYS

\begin{tabular}{cccc}
\hline Material & Elemen Struktur & Dimensi & Element Type \\
\hline & Ringbalk & $200 \times 400 \times 4000$ & \\
Beton & Balok & $200 \times 400 \times 4000$ & \\
& Sloof 1 dan 2 & $200 \times 400 \times 4000$ & SOLID65 \\
& Kolom & $300 \times 300 \times 4000$ & \\
Batu Bata & Dinding & $100 \times 200 \times 50$ & SOLID65 \\
Baja & Tumpuan & $300 \times 300 \times 100$ & SOLID185 \\
\hline
\end{tabular}

\section{Hasil Dan Pembahasan}

Berdasarkan hasil dari analisis software ANSYS Ed. pada kondisi beban ultimit dapat diketahui pola tegangan von misses, dan pola retak yang terjadi pada setiap model benda uji.

\subsection{Portal Satu Bentang}

\section{a) Tegangan Von Misses}

Gambar 5 menunjukkan model bangunan portal satu bentang yang tidak mengalami penurunan tumpuan. Dari Gambar 5 menunjukkan intensitas tegangan von misses yang terbesar terjadi pada pertemuan kolom dengan balok lantai dasar, yaitu sebesar 3.99 MPa, dan dibagian bawah pojok dinding bata pada kolom tepi, yaitu sebesar 1.25 MPa (Gambar 5.(i)).

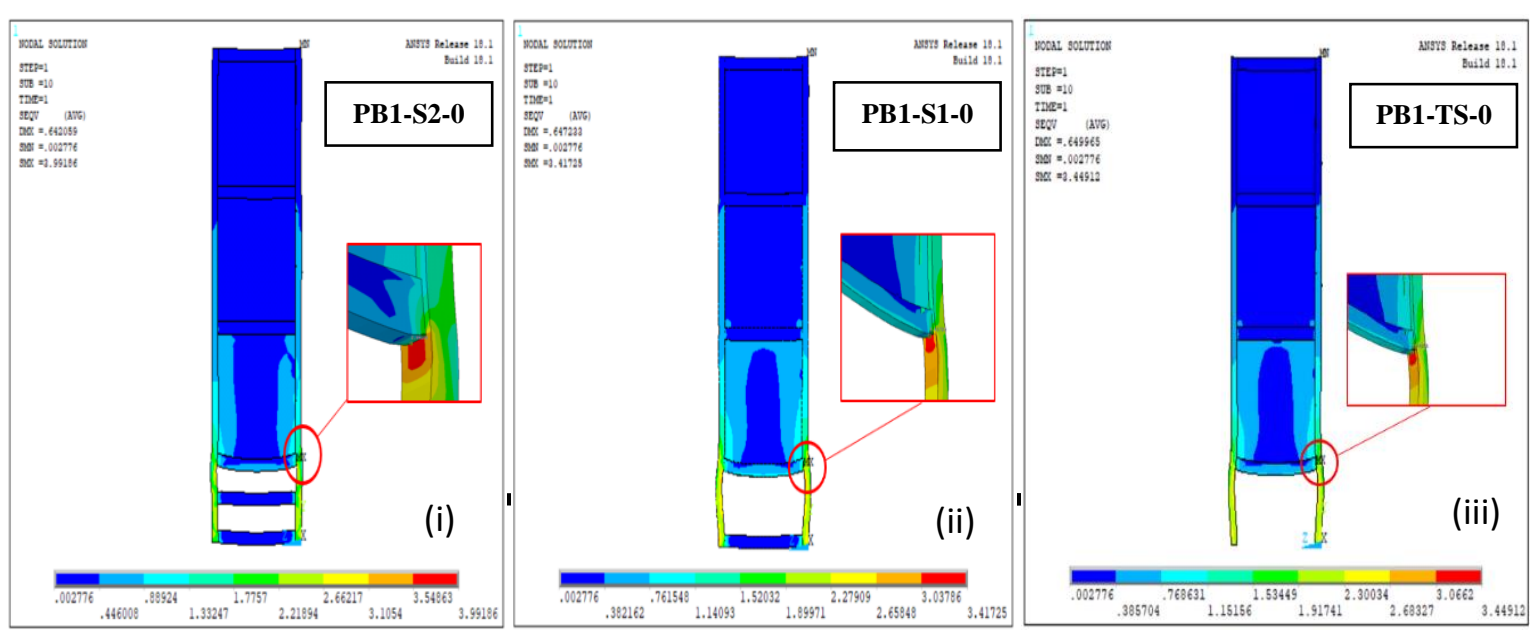

Gambar 5. Tegangan von misses portal satu bentang yang tidak mengalami penurunan tumpuan 
Gambar 6 menunjukkan model bangunan portal satu bentang yang mengalami penurunan pada tumpuan kanan, penurunan maksimum terjadi pada model 6.(i) sebesar $42 \mathrm{~mm}$, 6.(ii) sebesar $40 \mathrm{~mm}$, dan 6.(iii) sebesar $36 \mathrm{~mm}$. Dari Gambar 6 menunjukkan intensitas tegangan von misses yang terbesar terjadi pada pertemuan bagian bawah kolom yang tidak turun dengan balok sloof pertama, yaitu sebesar 22.44 MPa (6.(i)), dan dibagian bawah sisi dinding bata pada kolom tepi yang turun, yaitu sebesar 1.65 MPa. (6.(ii)).
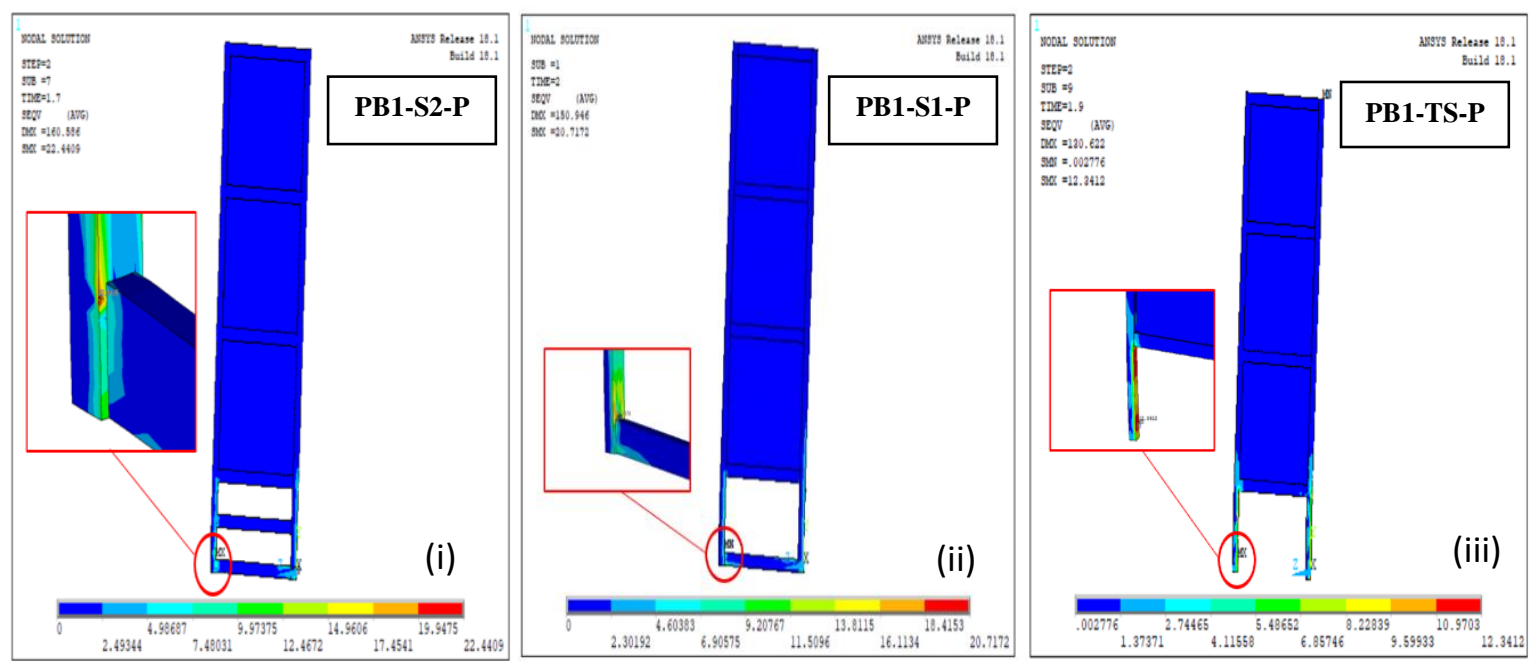

Gambar 6. Tegangan von misses model portal satu bentang yang mengalami penurunan tumpuan kanan

\section{b) Pola Retak}

Gambar 7 menunjukkan model bangunan portal satu bentang yang tidak mengalami penurunan tumpuan. Gambar 7 menunjukkan bahwa struktur tidak mengalami keretakan, sehingga penggunaan balok sloof 1 dan 2 tidak berpengaruh pada kerusakan struktur.

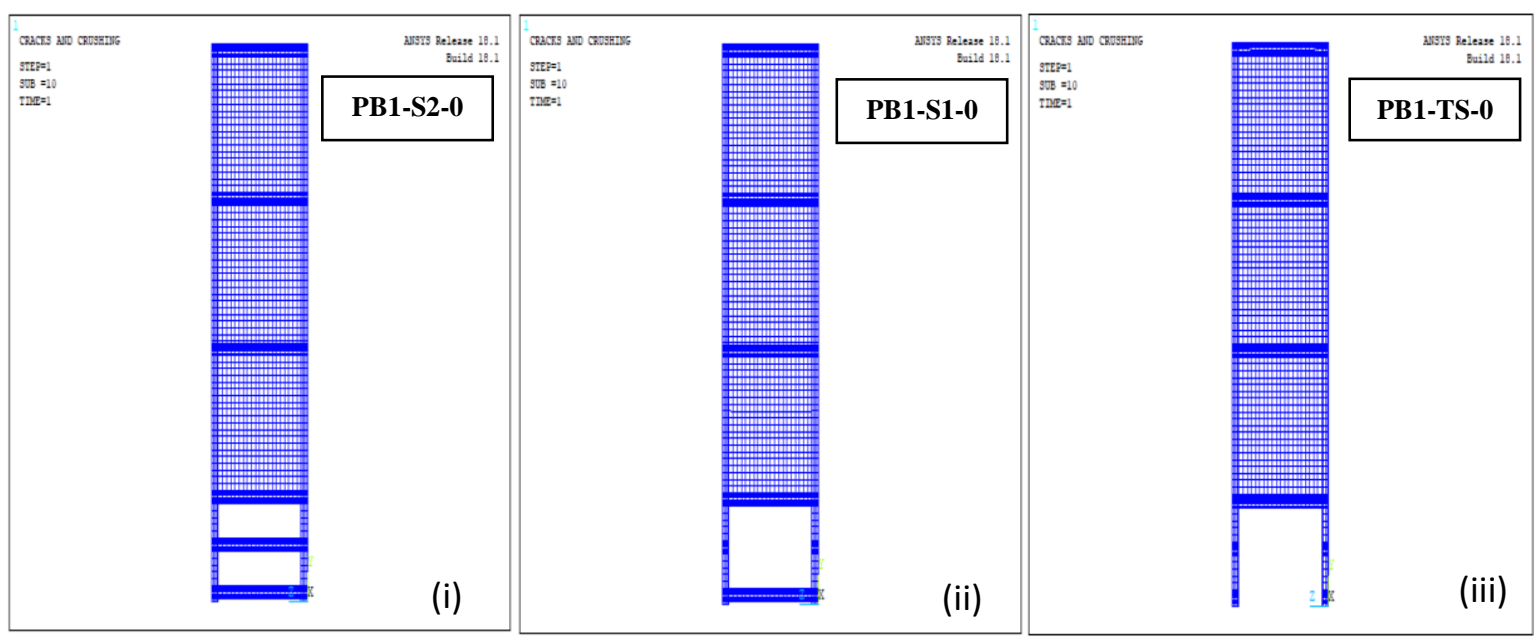

Gambar 7. Pola retak model portal satu bentang yang tidak mengalami penurunan tumpuan

Gambar 8 menunjukkan model struktur portal satu bentang yang mengalami penurunan pada tumpuan kanan. Penurunan maksimum terjadi pada model 8.(i) sebesar $42 \mathrm{~mm}$, 7.(ii) sebesar $40 \mathrm{~mm}$, dan 8.(iii) sebesar $36 \mathrm{~mm}$. Gambar 7 menunjukkan bahwa bangunan yang menggunakan balok sloof 1 dan 2 kerusakan hanya terjadi pada kolom dan balok sloof (8.(i) dan 8.(ii)), sedangkan bangunan 
yang menggunakan balok sloof 1 (8.(ii)) dan tidak menggunakan balok sloof (8.(iii)) telah terjadi keretakan diagonal pada pojok bawah dinding bata membentuk huruf $\mathrm{V}$ terbalik, sehingga penggunaan balok sloof 1 dan 2 mempengaruhi pola kerusakan struktur.

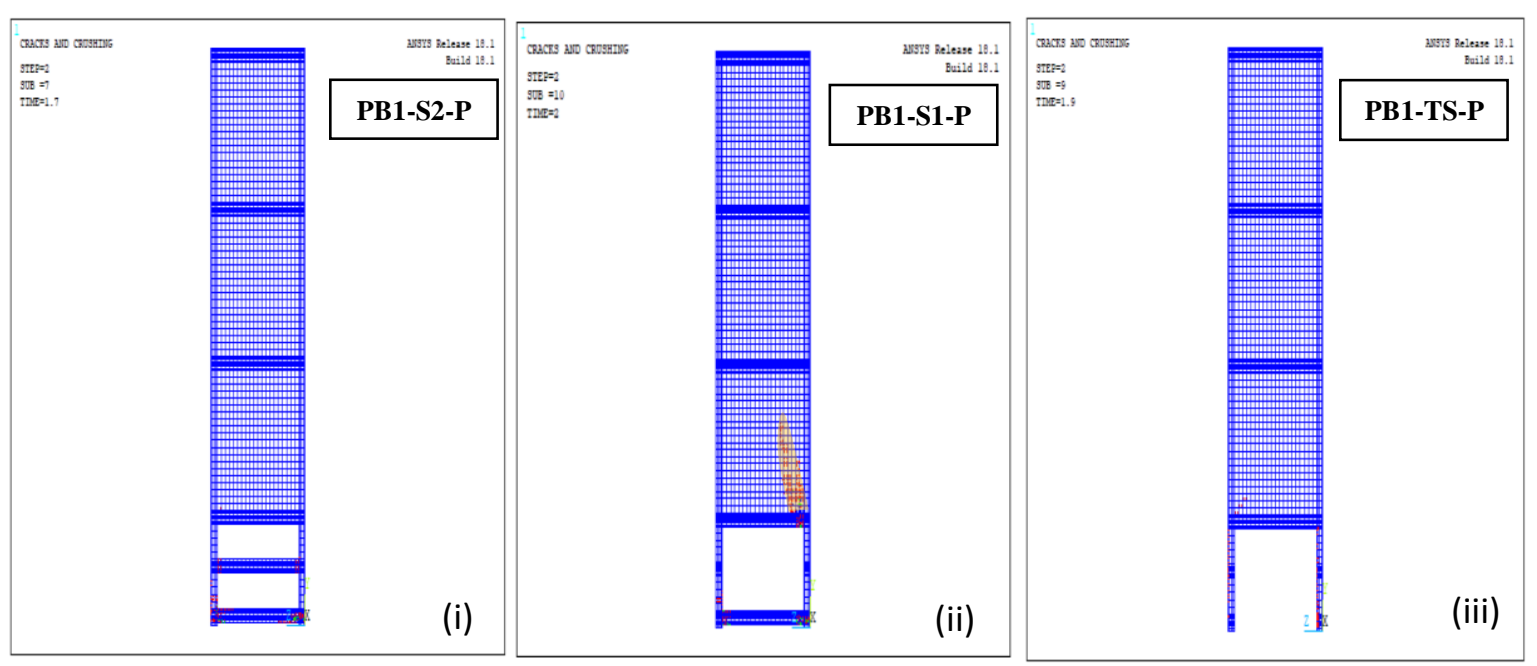

Gambar 8. Pola retak model portal satu bentang yang mengalami penurunan tumpuan kanan

\subsection{Portal Dua Bentang}

\section{a) (Kriteria) Tegangan Von Misses}

Gambar 9 menunjukkan model bangunan portal dua bentang yang tidak mengalami penurunan tumpuan. Gambar 9 menunjukkan intensitas tegangan von misses yang besar terjadi pada pertemuan kolom tepi dengan balok lantai dasar, yaitu sebesar 5.18 MPa (9.(i)), dan dibagian bawah pojok dinding bata pada kolom tepi, yaitu sebesar 2.73 MPa (9.(iii)).
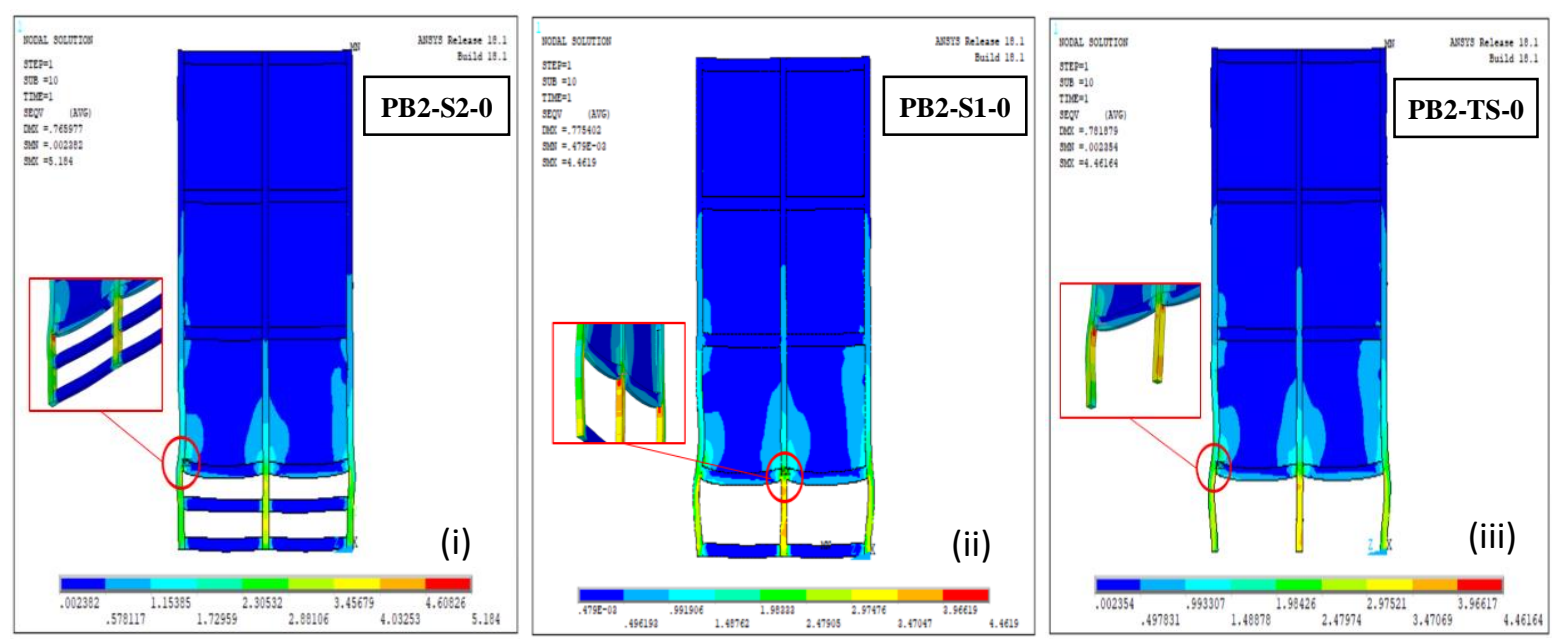

Gambar 9. Tegangan von misses model portal dua bentang yang tidak mengalami penurunan tumpuan

Gambar 10 menunjukkan model bangunan dua bentang yang mengalami penurunan tumpuan tengah, penurunan maksimum terjadi pada model 10.(i) sebesar $1.4 \mathrm{~mm}, 10$.(ii) sebesar 1,6 mm, dan 10.(iii) sebesar $1.6 \mathrm{~mm}$. Gambar 10 menunjukkan intensitas tegangan von misses yang besar terjadi pada pertemuan bagian bawah kolom tengah yang turun dengan balok sloof pertama, yaitu sebesar 10.59 
MPa (10.(i)), dan dibagian pojok dinding bata pada kolom tepi lantai 2 yang tidak turun, yaitu sebesar 3.91 MPa (10.(iii)).

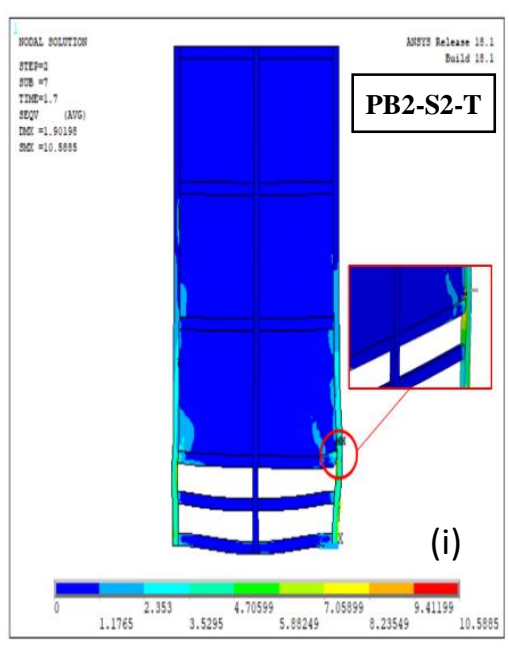

Gambar 10. Tegangan
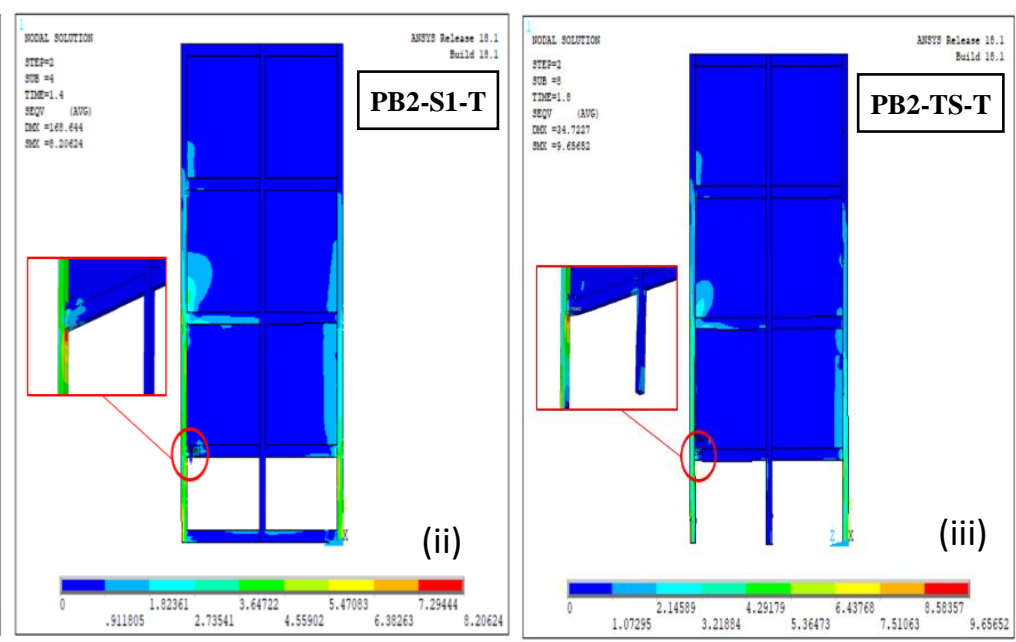

von misses model portal dua ben
penurunan tumpuan tengah

Gambar 11 menunjukkan model struktur portal dua bentang yang mengalami penurunan tumpuan tepi kanan, penurunan maksimum terjadi pada model 11.(i) sebesar $4 \mathrm{~mm}$, 11.(ii) sebesar $4 \mathrm{~mm}$, dan 11.(iii) sebesar $4 \mathrm{~mm}$. Gambar 11 menunjukkan intensitas tegangan yang besar terjadi pada pertemuan bagian bawah kolom tengah yang tidak turun dengan balok lantai dasar, yaitu sebesar 12.79 $\mathrm{MPa}$ (11.(ii)), dan dibagian sisi dinding bata pada kolom tengah yang tidak turun, yaitu sebesar 3.52 MPa. (11.(iii)).
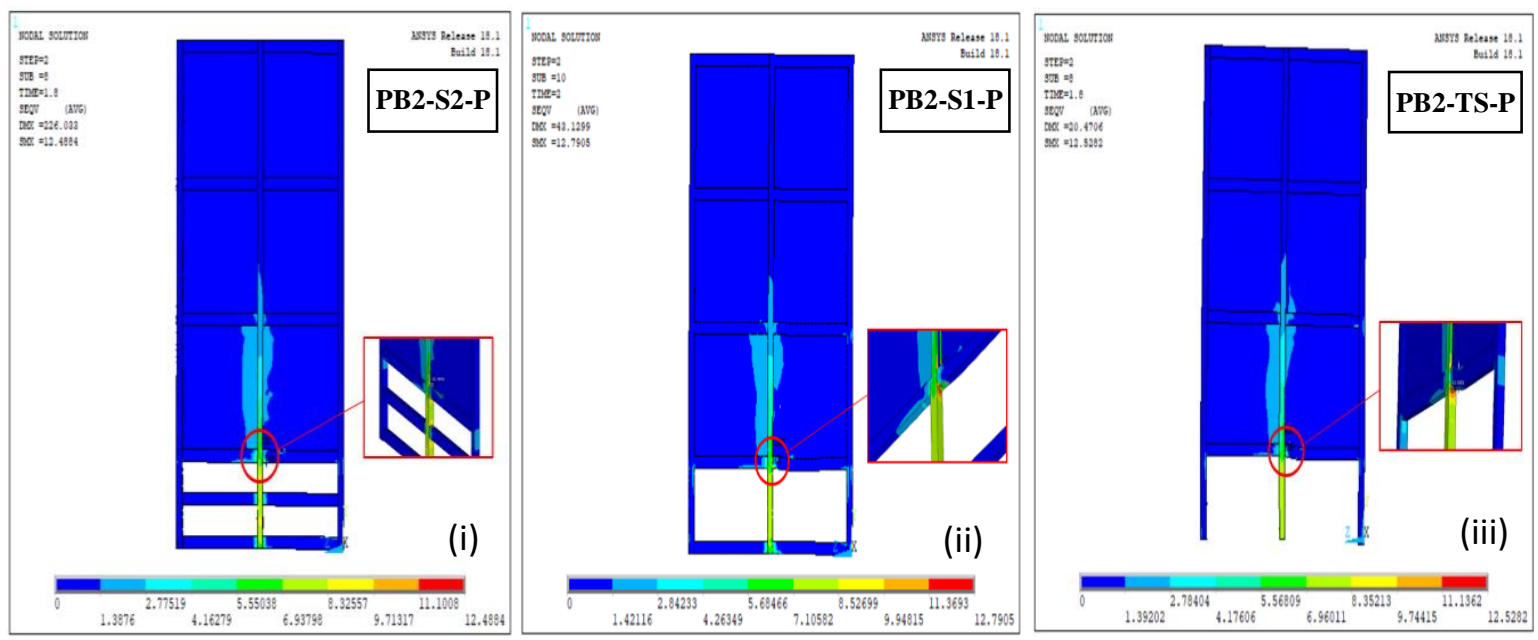

Gambar 11. Tegangan von misses model portal dua bentang yang mengalami penurunan tumpuan tepi kanan

\section{b) Pola Retak}

Gambar 12 menunjukkan model struktur portal dua bentang yang tidak mengalami penurunan tumpuan. Gambar 12 menunjukkan bahwa struktur mengalami pola keretakan yang sama yaitu terjadi keretakan dibagian kolom tengah pada pojok bawah dinding bata, sedangkan elemen yang lain masih dibawah tegangan tarik beton dan diiding bata sehingga masih belum mengalami keretakan. 


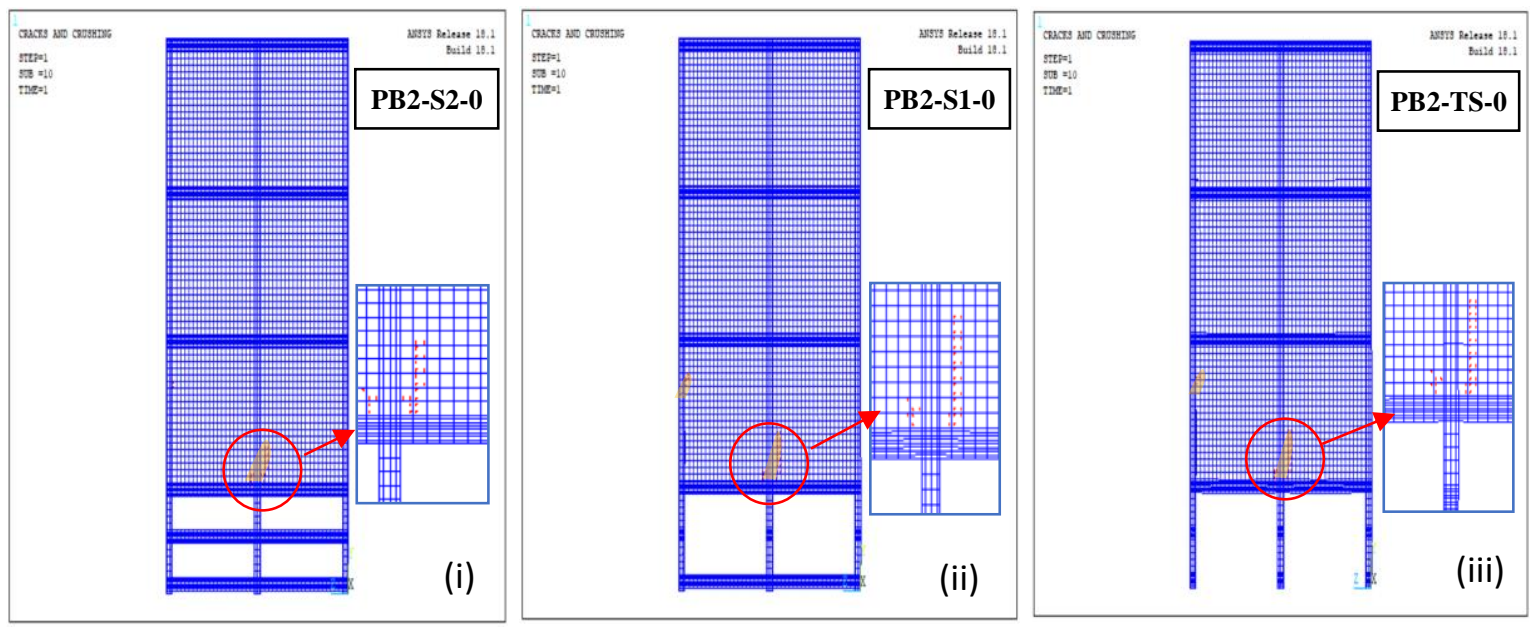

Gambar 12. Pola retak model portal dua bentang yang tidak mengalami penurunan tumpuan

Gambar 13 menunjukkan model bangunan dua bentang yang mengalami penurunan tumpuan tengah, penurunan maksimum terjadi pada model 13.(i) sebesar $1.4 \mathrm{~mm}$, 13.(ii) sebesar $1.6 \mathrm{~mm}$, dan 13.(iii) sebesar $1.6 \mathrm{~mm}$. Dari Gambar 13 menunjukkan bahwa bangunan yang menggunakan balok sloof 1 dan 2 kerusakan hanya terjadi pada pojok bawah kolom tepi dinding bata dengan pola retak diagonal membentuk huruf terbalik $\mathrm{V}$, sedangkan bangunan yang menggunakan balok sloof 1 dan tidak menggunakan balok sloof kerusakan hanya terjadi pada setiap pojok dinding bata.

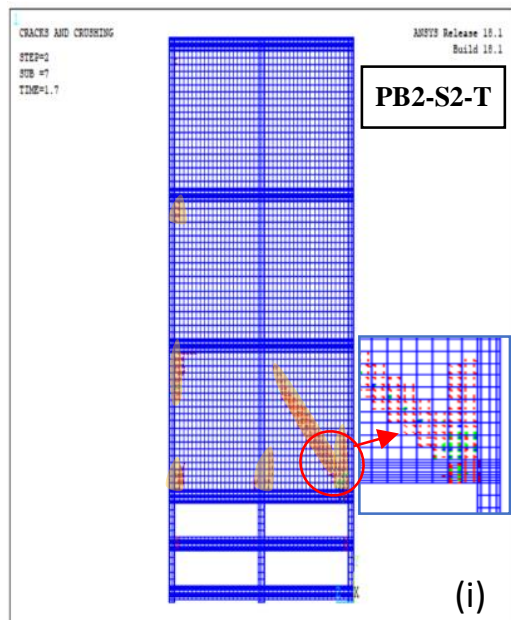

(i)

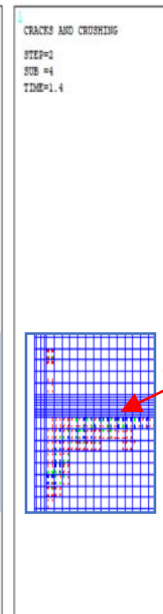

Gambar 13. Pola retak model portal dua bentang yang mengalami penurunan tumpuan tengah
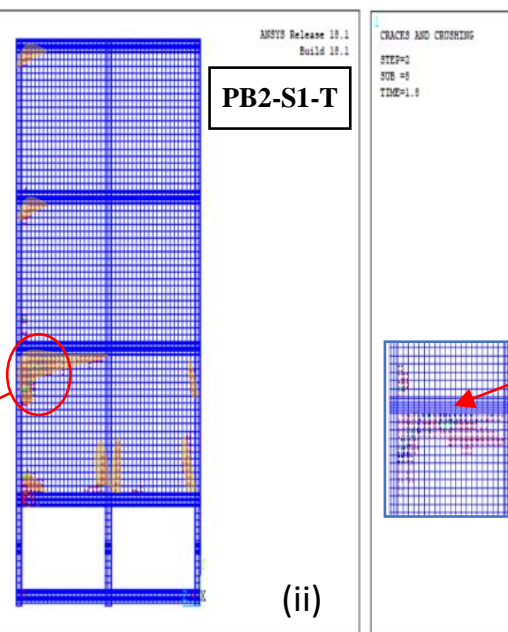

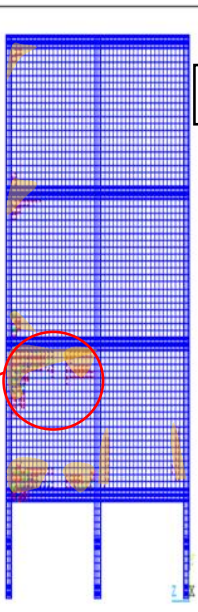

(iii)

Gambar 14 menunjukkan model bangunan dua bentang yang mengalami penurunan tumpuan tepi kanan, penurunan maksimum terjadi pada model 14.(i) sebesar $4 \mathrm{~mm}$, 14.(ii) sebesar $4 \mathrm{~mm}$, dan 14.(iii) sebesar $4 \mathrm{~mm}$. Gambar 14 menunjukkan bahwa struktur portal yang menggunakan balok sloof 1 dan 2 kerusakan terjadi pada bagian tumpuan balok sloof 1,2 dan balok lantai dasar, dan pada pojok bawah kolom tengah dinding bata dengan pola retak diagonal membentuk huruf $\mathrm{V}$, sedangkan bangunan yang menggunakan balok sloof 1 dan tidak menggunakan balok sloof kerusakan terjadi pada balok lantai dasar dan pada pojok bawah kolom tengah dinding bata dengan pola retak diagonal membentuk huruf $\mathrm{V}$, sehingga penggunaan balok sloof 1 dan 2 memiliki pola kerusakan struktur yang sama yaitu pola retak diagonal pada dinding bata. 


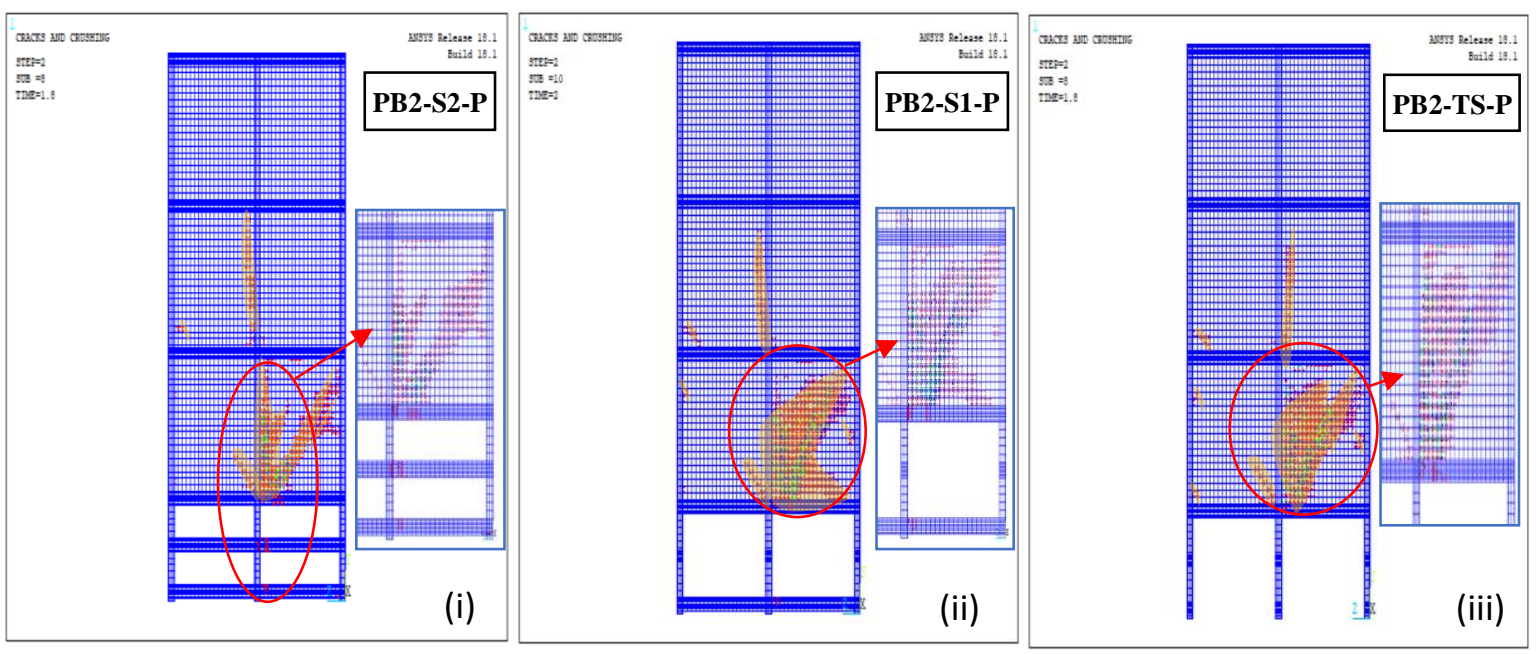

Gambar 14. Pola retak model portal dua bentang yang mengalami penurunan tumpuan tepi kanan

Berdasarkan pola retak yang terjadi, secara umum dapat disimpulkan bahwa pola retak dinding bata yang terjadi pada bangunan satu bentang yang mengalami penurunan tumpuan kanan atau kiri (Gambar 15.(i) dan 15.(ii)), dan pada bangunan dua bentang yang mengalami penurunan tumpuan tengah adalah retak diagonal yang membentuk huruf $\mathrm{V}$ terbalik (Gambar 15.(iii)).

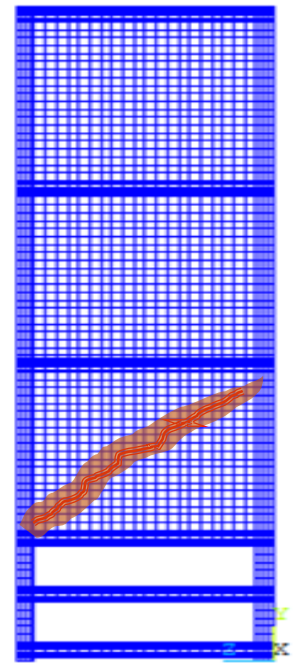

(i) Tumpuan Kiri Turun

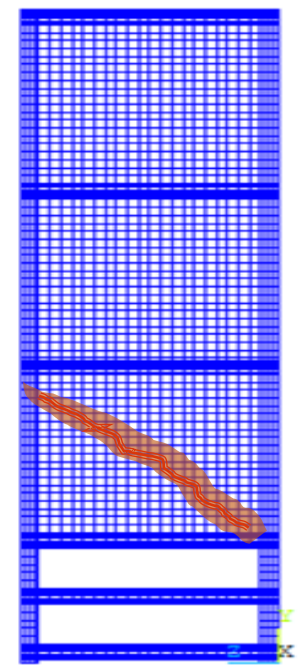

(ii) Tumpuan Kanan Turun

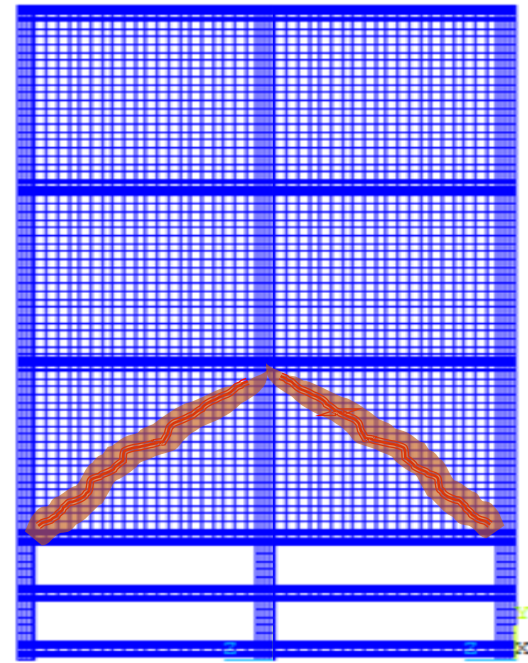

(iii) Tumpuan Tengah Turun

Gambar 15. Pola retak pada dinding bata jika kolom tepi atau tengah yang mengalami penurunan pondasi

Pola retak dinding bata yang terjadi pada bangunan dua bentang yang mengalami penurunan tumpuan tepi adalah retak diagonal pada pojok bawah kolom tengah dinding bata dengan membentuk huruf $\mathrm{V}$ (Gambar 16). 


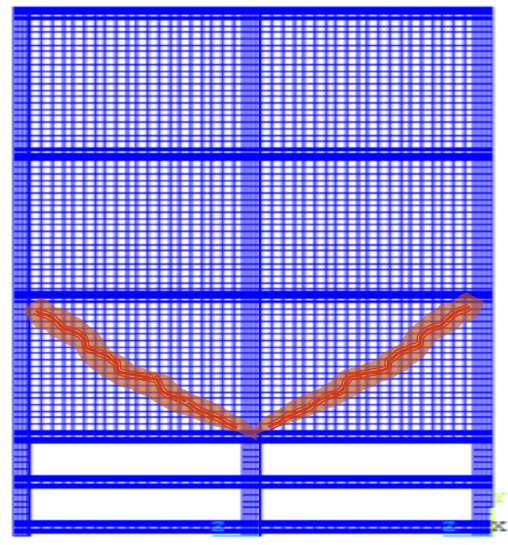

Gambar 16. Pola retak pada dinding bata jika kolom tepi yang mengalami penurunan pondasi

\section{Kesimpulan}

Kesimpulan dari hasil analisis pemodelan software ANSYS Ed. terhadap struktur portal beton dengan dinding pasangan batu bata adalah Penggunaan balok sloof pada pondasi yang mengalami penurunan tidak seragam (mewakili tanah lunak) akan mempengaruhi pola kerusakan elemen struktur (balok, sloof, kolom, dan dinding pasangan batu bata), Penggunaan balok sloof pada pondasi yang tidak mengalami penurunan (mewakili tanah keras) tidak mempengaruhi pola kerusakan elemen struktur tetapi akan meningkatkan derajat ketidaktentuan statis struktur. Pola retak dinding bata yang terjadi pada bangunan satu bentang yang mengalami penurunan tumpuan kanan atau kiri adalah retak diagonal yang membentuk huruf $\mathrm{V}$ terbalik (tegangan yang terjadi melebihi tegangan retak dinding pasangan batu bata $0.71 \mathrm{MPa}$ ). Pola retak dinding bata yang terjadi pada bangunan dua bentang yang mengalami penurunan tumpuan tepi adalah retak diagonal pada pojok bawah kolom tengah dinding bata dengan membentuk huruf $\mathrm{V}$ (tegangan yang terjadi melebihi tegangan retak dinding pasangan batu bata $0.71 \mathrm{MPa}$ ). Pola retak dinding bata yang terjadi pada bangunan dua bentang yang mengalami penurunan tumpuan tengah adalah retak diagonal yang membentuk huruf $\mathrm{V}$ terbalik (tegangan yang terjadi melebihi tegangan retak dinding pasangan batu bata $0.71 \mathrm{MPa}$ ). Lokasi elemen struktur yang berpotensi mengalami kerusakan dapat diketahui melalui hasil analisis tegangan von misses.

\section{Ucapan Terima Kasih}

Ucapan terima kasih kepada Lembaga Penelitian Universitas Lambung Mangkurat melalui Program Hibah Dosen Wajib Meneliti 2020 yang telah memberikan bantuan dana sehingga terlaksananya penelitian ini.

\section{Daftar Pustaka}

Ch. V. Uday Vyas, B.V. Venkatarama Reddy, 2010. Prediction of Solid Block Masonry Prism Compressive Strength Using FE Model, Materials and Structures (2010) 43:719-735.

Darmansyah Tjitradi, 2006. Modifikasi Kurva Tegangan Regangan Beton Kent Park (1971) Menjadi Blok Tegangan Segiempat Ekivalen, Jurnal Aksial, Vol.8, No.1, Hal. 1-13. 
D.C. Wijeyesekera, L. Numbikannu, T.N.H.T. Ismail, I Bakar. 2016. Mitigating Settlement of Structures founded on Peat, IOP Conference Series: Materials Science and Engineering, Volume 136, Soft Soil Engineering International Conference 2015 (SEIC2015) 27-29 October 2015, Langkawi, Malaysia.

German Diaz. 2010. Seismic behaviour of composite wall systems subjected to different levels of seismic action and with different levels of protection, Master thesis (pre-Bologna period), RWTH AACHEN Stahlbau university, Germany.

Hardiyatmo, H. C, 2002. Teknik Pondasi I, Penerbit PT. Beta Offset, Yogyakarta.

Huat B.B.K., Asadi A. 2013. Most Current Ideas and Latest Advances in Soil Improvement at University Putra Malaysia, Proceeding of Soft Soil Engineering International Conferences (SEIC'13), Sarawak, Malaysia.

Huat B.B.K., Othman K., Jaafar A.A. 1995. Geotechnical Properties of Malaysia Marine Clays, Journal - Institution of Engineers Malaysia.

Huat B.B K., Maail S., Mohamed T.A. 2005. Effect of Chemical on the Engineering Properties Of Tropical Peat Soil, American Journal of Applied Sciences, Science Publication.

I. Saifullah, M. Nasir-uz-zaman, S.M.K. Uddin, M.A. Hossain, M.H. Rashid, 2011. Experimental and Analytical Investigation of Flexural Behavior of Reinforced Concrete Beam, International Journal of Engineering \& Technology IJET-IJENS Vol: 11 No: 01.

Komarudin. 2017. Studi Diferential Settlement Akibat Adanya Penambahan Sirtu Pada Kelompok Tiang Di Bawah Pondasi Tangki, Jurnal Gema Wiralodra, No. 1 Vol. VIII, April 2017.

L. Dahmani, A. Khennane, and S. Kaci, 2010. Crack Identification In Reinforced Concrete Beams Using ANSYS Software, Strength of Materials, Vol. 42, No. 2, Springer Science + Business Media, Inc.

N.O. Mohamad, C.E. Razali, A.A.A. Hadi, P.P. Som, B.CEng, M.B. Rusli, F.R. Mohamad, 2016. Challenges in Construction Over Soft Soil - Case Studies in Malaysia, OP Conference Series: Materials Science and Engineering, Volume 136, Soft Soil Engineering International Conference 2015 (SEIC2015) 27-29 October 2015, Langkawi, Malaysia.

Reza J. C, Abolfazl M., 2010. Adjacent Building Induced Settlement Reduction in Residential Constructions, ISFGE 2010 Forensic Approach to Analysis of Geohazard Problems, 14-15 Dec. 2010, Mumbai.

Rufaizal C. M., Anuar Kasa, Siti Fatin Mohd Razali, 2019. A Review Of Road Embankment Stability On Soft Ground: Problems And Future Perspective, IIUM Engineering Journal, Vol. 20, No. 2.

Skempton, A.W dan MacDonal, D.H., 1955, A survey of Comparisons between Calculated and Observed Settlement of Structures on Clay, Conf. on Correlation of Calculated and Observed tresses and Displacement, ICE, London, pp.318-337.

SNI 1727:2013. Beban Minimum untuk Perancangan Bangunan Gedung dan Struktur Lain, BSN. 